\title{
GENOTYPES OF THE CACOECIA PODANA SC. LARVAE IN THE AES-1 ESTERASE LOCUS DIFFER IN THEIR FOOD MICRO-NICHES
}

\author{
ANDRIY SIMCHUK
}

\begin{abstract}
Intergenotypic differentiation of trophic niche was studied in the system "apricot (Prunus armeniaca L.) - Cacoecia podana Sc.". C. podana larvae, carried alternative Aes-1 genotypes, were found to prefer host plant leaves, differing by length and stiffness, in their diets. Trophic micro-niches for each genotype coincided with the whole population niche in width, but differed by their optimums. There data are discussed in respect to the herbivore food specialization and population dynamics.
\end{abstract}

Keywords: gene-environment relationship, niche width, food specialization, Cacoecia podana Sc.

\section{INTRODUCTION}

Grinnell, (1917, cited after Pianka, 1978 [1]) seem to be first who used the term "niche". As a niche he awakened that functional role, which an organism plays in natural community. More common approach to niche description was offered by Hutchinson in 1957 [2]. He described a niche as a range of conditions, at which an individual (or population) lives and reproduces itself. Later Odum in 1959 [3] defined ecological niche as a position, or status of an organism in natural community, or ecosystem, which follows from its adaptations, physiological reactions and specific behavior. Thus, today the term "niche" is awaked enough wide and contains some components, one of which is a trophic or food niche.

Special attention to the trophic niche of a population may be addressed due to its role in determination of matter and energy flow into the given link of food chain. Some organisms (polyphagous) have wide trophic niches, other (monophagous) have narrow trophic niches. Ecologists usually describe trophic niche for the whole population. But from the genetic point of view, intrapopulative differentiation of food niche. is more interesting than its general width. From 60-70 years of previous century the whole population niche has been devided into the two basic components of its width: "interphenotypic" component and "intraphenotypic" component $[4,5,6]$. If a population consists of specialized individuals, which exploit slowly overlapping resources, then the interphenotypic component mainly contributes to the population niche width. If the population contains unspecialized individuals, and each its member may successfully exploit all the range of resources, then the intraphenotypic component of niche width reaches its maximum value. However, 
the real populations presumably exist between these two extreme limits. Nevertheless, experimental data on differentiation of trophic niche in diverse organisms have been rarely appeared in literature.

Earlier the differentiation of trophic niche was documented in monophagous Tortrix viridana L. $[7,8]$. Presented research is focussed on an attempt to reveal genetic differentiation of trophic niche in polyphagous herbyvore, studying system "apricot (Prunus armeniaca L.) - Cacoecia podana Sc. ". Results may be interesting in respect to understanding mechanisms of interaction between these two species and for developing of the ecologically based approaches for the pest control.

\section{ReSEARCH OBJeCTIVE, METHODOLOGY}

The research was performed in the Cacoecia podana Sc (Lepidoptera, Tortricidae) population. Material was collected in 2016 spring from three trees of apricot (Prunus armeniaca), which grow in "Agrarnoe" village, situating $5 \mathrm{~km}$ North from Simferopol city (Crimean Autonomous Republic, Ukraine). Fifthinstar larvae were collected simultaneously with the leaves, on which they fed. Each larva placed in separate vial together with proper leaf. The same day that material was delivered in laboratory. The larvae were measured (body width and length), enumerated and placed in refrigerator, and each leaf was measured (length) and taken to define its stiffness using device, consisting of punch on spring. Leaf stiffness was expressed in symbolic units (distance in $\mathrm{mm}$, which must be passed by a spring, pushing the punch to made a hole in a leaf tissue).

As it proceeds from the task of the investigation, the genes participating in food relations of the organism should be preferably included in the study. Thus, preference was given to allozyme-analysis. Allozymes are phenotypic signs, carrying one or another function. Some of them participate in the trophic relations of the insect with its host plant, in digestion or protection from plant defensive compounds. The technique of electrophoretic separation was used to obtain allozyme spectrums [9]. Esterase allozymes were chosen as genetic markers, because, as it has been shown earlier for T. viridana, this enzyme immediately participates in insect interaction with host plant, plays a role in detoxification of phenols [10], and displays a relation with host plant's leaf $\mathrm{pH}$ and stiffness [7]. Specification of the esterase isozymes were performed using appropriate inhibitors. Gels with the esterases separated after the electrophoresis were incubated during $5 \mathrm{~min}$ at $37^{0} \mathrm{C}$ with following solutions: paraoxon $\left(10^{-4} \mathrm{M}\right)$, inhibiting carboxyl-esterase; $\mathrm{CuSO}_{4}\left(10^{-3} \mathrm{M}\right)$, inhibiting aril-esterase; all the inhibitors were solved in 0,05 M tris- $\mathrm{H} \mathrm{Cl}$ buffer, $\mathrm{pH}$ 7,2.

\section{RESUlTS AND DisCUSSION}

Electrophoretic spectrum of the esterases from C. podana consists of acetyl-esterase, aril-esterase and carboxyl-esterase, which after electrophoretic procedure were located in the same part of the gel (Fig. 1a). Specific inhibitors paraoxon, inhibiting carboxyl-esterase (Fig. 1b); $\mathrm{CuSO}_{4}$, inhibiting aril-esterase (Fig. 1c)) were used for their separation. Simultaneous application of these inhibitors allowed to expose only acetyl-esterase (Fig. 1d). Nominally this enzyme possesses clear polymorphism in C. podana and its allozymes were used as markers of the two Aes-1 alleles: F and S. 
(a)

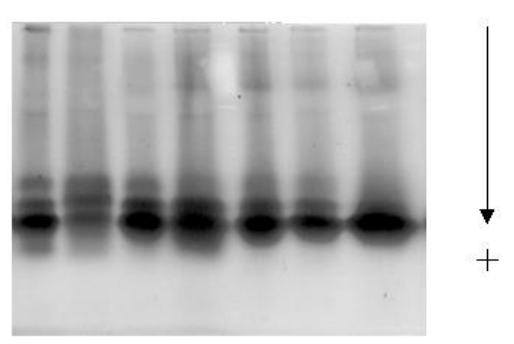

(c)

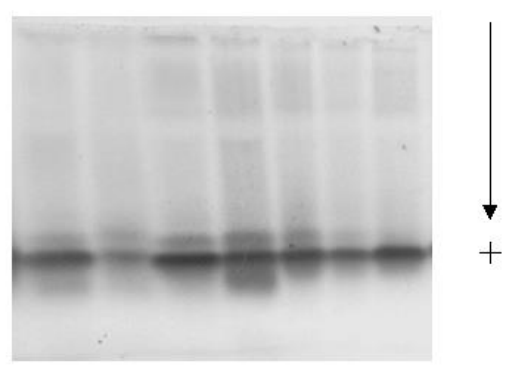

(b)

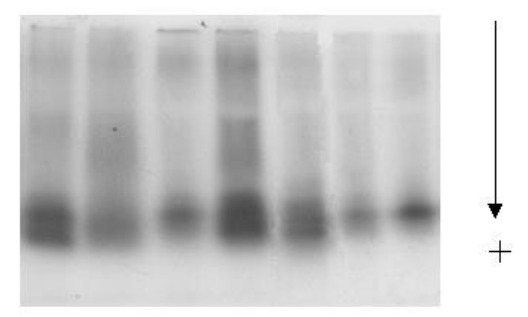

(d)

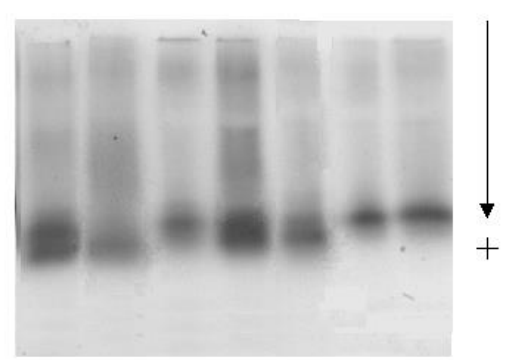

Fig. 1. Electrophoretic spectrums of the esterases from C. podana: (a) common spectrum; $(b)$ acetyl-esterase and arilesterase (treatment by paraoxon); (c) acetyl-esterase and carboxyl-esterase (treatment by $\mathrm{CuSO}_{4}$ ); (d) acetyl-esterase (treatment by both inhibitors simultaneously).

Statistic parameters of host plant leaves, on which the insect larvae of different Aes-1 genotypes fed, are presented in Tab. 1. Only FF and FS genotypes significantly differ between themselves in stiffness variance of the leaves, which they ate. Variance value for FF and leaf length distributions for alternative genotypes essentially differed in asymmetry and excess (Tab. 1). Thus, these distributions are different, and individuals of alternative Aes-1 genotypes, hence, preferred to feed on leaves of different properties.

\begin{tabular}{|c|c|c|c|c|c|c|}
\hline \multirow{2}{*}{ Parameter } & \multicolumn{6}{|c|}{ Host plant feature } \\
\cline { 2 - 7 } & \multicolumn{3}{|c|}{ Leaf length $(\mathrm{mm})$} & \multicolumn{3}{c|}{ Leaf stiffness (s.u.) } \\
\cline { 2 - 7 } & \multicolumn{3}{|c|}{ Aes-1 genotype } & FF & FS & SS \\
\cline { 2 - 7 } & FF & FS & SS & 2,83 & 2,09 & 1,99 \\
\hline Mean & 39,00 & 36,16 & 42,25 & 0,16 & 0,08 & 0,11 \\
\hline Standard Error & 3,50 & 1,81 & 2,45 & 0,26 & 0,08 & 0,18 \\
\hline Variance & 134,80 & 62,58 & 119,99 & $-0,64$ & $2,05^{* * *}$ & $-0,60$ \\
\hline Excess & $4,27^{* * *}$ & 0,30 & 0,50 & 0,13 & $-0,72$ & $-0,27$ \\
\hline Asymmetry & $1,85^{* *}$ & 0,48 & 0,85 & 10 & 14 & 17 \\
\hline $\mathrm{N}$ & 11 & 19 & 20 & & & \\
\hline
\end{tabular}

Tab. 1. Statistic parameters of host plant leaves, on which the Cacoecia podana larvae of different Aes-1 genotypes fed ("Agrarnoe" village, 2016): significant differences in leaf stiffness variances: FF vs. FS, $F=3,14^{*} ;{ }^{*}-P<0,05 ;{ }^{* *}-P<0,01$; ${ }^{* * *}$ - $P<0,001 ;$ asymmetry and excess estimates deviations of experimental distributions from normal distribution; $N-$ sample size. 

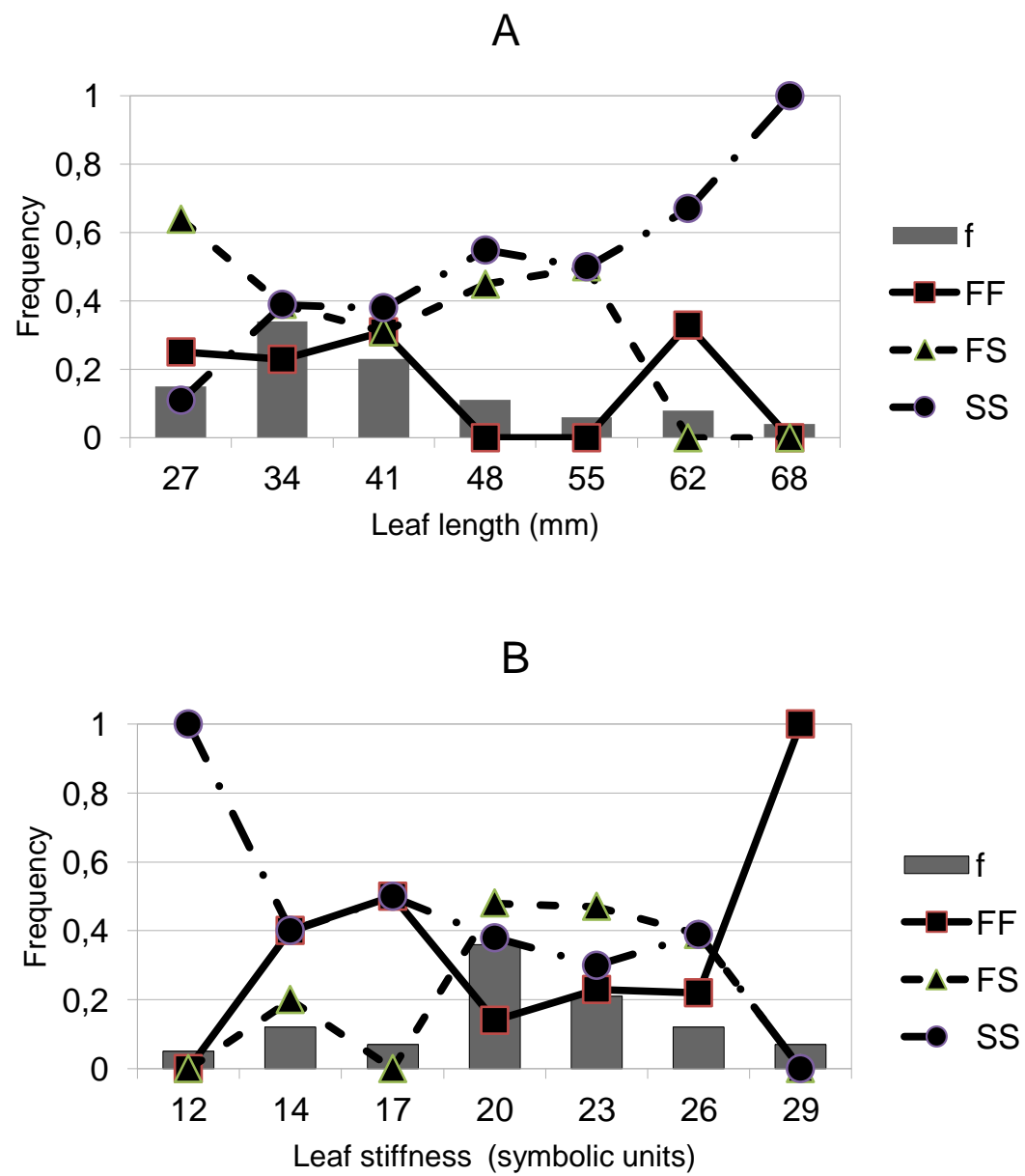

Fig. 2. The Aes-1 genotype frequencies in the classes of distributions on length (A) and stiffness (B) of host plant leaves, eaten by these genotype carriers: $q$-genotype frequency; $f$-rank frequency for leaf future distributions; significant relations with: leaf length $-F S, R=-0,80 ;$ d.f. $=5 ; P<0,05 ; S S, R=0,92 ;$ d.f. $=5 ; P<0,01$; leaf stiffness $-F S$, (rank correlation) $R r=$ 0,$96 ;$ d.f. $=5 ; P<0,05 ; S S, R=-0,80 ;$ d.f. $=5 ; P<0,05$.

Graphic form of the data presentation makes it clear the picture of inter-genotype differentiation of C. podana trophic niche. The Aes-1 genotype frequencies in the classes of host plant's leaf length and stiffness distributions are shown in Fig. 2. Only FS and SS genotypes indicated gene-environment relationships, showing statistically significant relations with both leaf futures. The FS genotype frequency was negatively related to leaf length, while SS frequency showed positive correlation with this sign (Fig. 2a).

Relationships became severally different when studying leaf stiffness as an environmental future (Fig. 2b)). Correlation coefficient for SS genotype was negative, whereas FS genotype frequency showed positive rank correlation with leaf stiffness. Leaf stiffness negatively correlated with the leaf length $(R=$ $-0,34 ; \mathrm{df}=40 ; \mathrm{P}<0,05)$ and this might be the cause of differences between these leaf features in relations with the insect genotype frequencies.

Found gene-environment relationships show intergenotypic differentiation of trophic niche in $C$. podana. Herewith, SS genotype preferred to feed on most "soft" leaves, and heterozygous individuals mainly ate the leaves of intermediate stiffness. The Individuals of FF genotype displayed a tendency to preference of more stiff leaves, but the relation was out of authenticity limits. At the same time, the fatness coefficient (body width/body length) of SS genotype carriers was correlated with leaf length ( $R$ $=0,47 ; \mathrm{df}=18 ; \mathrm{P}<0,05)$, while only fatness coefficient of the FF genotype carriers showed positive relation with the leaf stiffness $(R=0,65 ; \mathrm{df}=8 ; \mathrm{P}<0,05)$. Thus, FF genotype larvae reached maximum size 
when feeding on the stiff leaves, and this is an indirect argument in the favor of the statement that the larvae of FF genotype really preferred stiff leaves in their diet.

Earlier, intergenotypic differentiation of trophic niche was found in the system "oak - oak leafroller moth" [7]. Oak leafroller, T. viridana, is a monophagous herbivore and feeds only on oak leaves. Pts-4 and Est-4 genotypes showed relationships with $\mathrm{pH}$ and stiffness of host plant leaves. Both the studied loci were polyallelic in T. viridana, and many genotypes divided population trophic niche into narrow micro-niches. Each genotype had its own micro-niche, to which it was most adapted, i.e. larvae of given genotype might eat only leaves of certain properties and did not eat other leaves [7].

Some different picture was found in C. podana. In spite of intergenotypic differentiation of tropic niche, each of the genotype's micro-niche widths were practically coincided with the whole population niche width, although genotypes differ between themselves by optimums. Possibly, some other important factors might be not taken into the account, but herein reported data allow to consider $C$. podana as a species, which trophic niche width is mainly determined by intra-phenotypic component (see above).

Obviously, enzymes, coded by alternative alleles, in $C$ podana are less specialized than those in $T$. viridana. Widely specific digestive and protective enzymes may bring an evolutionary advantage to polyphagous C. podana, because they allow it to feed on different host plants. Such point of view is well coincided with the data on dependence of allozyme polymorphism level from the level of food specialization in insects. Monophages were more polymorphic than olygophages [11]. Olygophagous and polyphagous insects, producing few enzyme forms, are able to exploit wide trophic niche due to widely specialized digestive and protective enzymes.

Theoretical description of a model, in which genotypes differ in their requirement to environment, was elegantly developed and described by H. Levene [12]. F. J. Ayala used close notions for explanation of frequency-dependent selection and overcompensation effect, when polymorphic population exceeded uniform populations in productivity $[13,14]$. This effect may serve as a basis of an idea that the level of genetic variability may contribute to regulation of population density [15]. Actually, if alternative genotypes differ in their ability to utilize different resources, then polymorphic populations exploit heterogenous environment more efficiently than those uniform, and, hence may reach higher densities.

Detailed model of cyclic population dynamics, based on intergenotypic differentiation of trophic niche, was proposed and described for T. viridana [7]. However, strict differentiating selection is critical for the model. It is obvious that this condition is not actual for C. podana due to high plasticity of unspecialized enzymes. Therefore, proceeding from earlier proposed hypothesis, it may be concluded that cyclic, bimodal population dynamics should be inherent to species with prevailing intergenotypic component of niche width, while species with prevailing intragenotypic component of niche width should have sustainable dynamics with equilibrium density. Nevertheless, the data obtained may contribute to the development of pesticide-free method of the pest control in the garden. Analysis of the properties of host plants and the pest genetic structure may be useful for prognosis of pest densities on them and efficiency of the bio-preparations against the pest.

\section{REFERENCES}

[1] Pianka E.R. Evolutionary Ecology. Second edition. Harper and Row Publishers, New York, 1978.

[2] Hutchinson G.E. Concluding remarks. Cold Spring Harbor Symp. Quant. Biol., 22 (1957), 415-427. doi: 10.1101/SQB.1957.022.01.039

[3] Odum E.P. Fundamentals of Ecology (2nd ed.), Saunders, Philadelphia, 1959.

[4] Van Valen L. Morphological variation and width of the ecological niche. Amer. Natur., 99 (908) (1965), 377-390. doi: 10.1086/282379 
[5] Orians G.H. Ecological aspects of behavior. Chapter 11. In: Farner D.S., King J.R. (Eds.) Avian Biology, vol. 1, Academic press, New York, 1971.

[6] Roughgarden J. Evolution of niche width. Amer. Natur., 106 (952) (1972), 683-718. doi: 10.1086/282807

[7] Simchuk A.P, Ivashov A.V., Companiytsev V.A. Genetic patterns as possible factors causing population cycles in oak leafroller moth, Tortrix viridana L. Forest Ecology and Management, 113 (1999), 35-49.

[8] Simchuk A.P., Ivashov A.V. Ecological-genetic aspects of trophic preference partitioning in a microassemblage of oak herbivores. Zhurn. Obsch. Biol., 67 (1) (2006), 53-61.

[9] Gaal O., Medgyesi G.A., Vereczkey L. Electrophoresis in the Separation of Biological Macromolecules. Mir Publishers, Moscow, 1982.

[10] Ivashov A.V., Boyko, G.E., Simchuk A.P. Modification and utilization of the phenolic compaunds in the pubescent oak leaves by caterpillars of the oak leafroller moth and the gypsy moth. Zhurnal Obshcey Biologii, 53 (1992), 384 - 393.

[11] Verdick P. Genetic variability in mono- and olygophagous chrysomelid beetles at variance with the niche-width variation hypothesis. 20 Int. Congr. Entomol., Firenze, Aug. 25-31, 1996. Proc., Firenze., 1996, 38.

[12] Levene H. Genetic equilibrium when more than one ecological niche is available. Amer. Natur., 87 (836) (1953), 331-333. doi: 10.1086/281792

[13] Ayala F.J., Campbell C.A. Frequency-dependent selection. Annu. Rev. Ecol. and Syst., 5 (1974), 115-138.

[14] Tosic M., Ayala F.J. Density- and frequency-dependent selection at the Mdh-2 locus in Drosophila pseudoobscura. Genetics, 97 (1981), 679 - 701.

[15] Ayala F.J. Genotype, environment, and population numbers. Science, 162 (1968), 1453 - 1459.

Address: Andriy Simchuk, Vasyl Stefanyk Precarpathian National University, 57 Shevchenko St., IvanoFrankivsk 76018, Ukraine.

E-mail: andriy.simchuk@pnu.edu.ua.

Received: 10.11.2020; revised: 25.12.2020.

Сімчук Андрій. Генотипи дичинок Cacoecia podana Sc. в естеразному докусі Aes-1 розрізняються за своїми харчовими мікро-нішами. Журнал Прикарпатського університету імені Василя Стефаника, 7 (4) (2020), 27-33.

Міжгенотипичну диференціацію трофічної ніши вивчали в системі: абрикос (Prunus armeniaca L.) - всеїдна листовійка-товстунка Cacoecia podana Sc. Було встановлено, що личинки комахи різних генотипів в локусі Асе-1 надавали перевагу харчуванню листям, яке розрізнювалось за довжиною i жорсткостю. Трофічні мікроніши всіх генотипів співпадали з трофічною нішею всієї попуяяції за розміром, але розрізнювались за оптимумами. Частота генотипу FS негативно корелювала 3 розмірами листя рослини-хазяїна, а частота генотипу SS була позитивно зв'язана 3 цією ознакою. Кореляція для генотипу SS з жорсткістю ииста змінилася на негативну, тоді як генотип FS показував позитивний ранговий зв'язок з жорсткістю диста. Відмінності у зв'язках частот генотипів 3 довжиною та жорсткістю диста можуть пояснюватися тим, що ці дві ознаки дистя показади негативну кореляцію $(\mathrm{R}=-0,34 ; \mathrm{df}=40 ; \mathrm{P}<0,05)$. Швидше за все, зв'язок частот генотипів 3 довжиною диста виникає як наслідок кореляції між цією ознакою та жорсткістю. Представлені дані наочно показують міжгенотипичну диференціацію трофічної ніши всеїдної дистовійки. При цьому, носії генотипу SS надають перевагу харчуванню найбільш “м'яким" листям, а особини гетерозиготного генотипа листям з проміжною жорсткістю. Особини генотипу FF характеризувалися тенденцією до переваги 
найбільш жорсткого иистя, але зв'язок був за межами достовірності. Отримані дані обговорюються 3 точки зору харчової спеціалізації і характеру динаміки чисельності комахи.

Ключові слова: взаємодія типу ген-навколишне середовище, ширина ніши, харчова спеціалізація, Cacoecia podana Sc. 